\title{
RESTITUSI BAGI KORBAN TINDAK PIDANA: SEBUAH TAWARAN MEKANISME BARU
}

\author{
Fauzy Marasabessy ${ }^{1}$
}

\begin{abstract}
A criminal action may cause harm to others the victims of crime. To obtain such compensation, a victim of a criminal act can be the procedures provided by the Criminal Procedure Code the merger lawsuit for damages. After the enactment of Law No. 13 of 2006 on Witness and Victim Protection, all victims of crime are also given the option to apply for compensation in the form of restitution through the Agency. However, there are some problems that arise in the implementation of mechanisms to obtain restitution for the victims of such crime. The problems are not just about rules, but also the institution that is authorized to assist victims of crime get the right to restitution.
\end{abstract}

Keywords: criminal, victim, compensation, restitution, Agency, prosecutors, public prosecutor

\begin{abstract}
Abstrak
Suatu tindak pidana dapat menimbulkan kerugian bagi orang lain yakni korban tindak pidana. Untuk mendapatkan ganti kerugian tersebut, seorang korban tindak pidana dapat menempuh prosedur yang disediakan oleh KUHAP yakni penggabungan perkara gugatan ganti kerugian. Setelah berlakunya Undang-Undang Nomor 13 Tahun 2006 tentang Perlindungan Saksi dan Korban, semua korban tindak pidana juga diberikan pilihan untuk mengajukan permohonan ganti kerugian yang berupa restitusi melalui LPSK. Akan tetapi, ternyata ada beberapa masalah yang timbul dalam implementasi mekanisme untuk mendapatkanrestitusi bagi korban tindak pidana tersebut. Masalah-masalah tersebut tidak hanya mengenai aturannya, tetapi juga mengenai lembaga yang diberi kewenangan untuk membantu korban tindak pidana mendapatkan hak atas restitusinya.
\end{abstract}

Kata kunci: pidana, korban, ganti rugi, restitusi, LPSK, jaksa, penuntut umum

\section{Pendahuluan}

Seseorang yang menjadi korban tindak pidana harus menghadapi masalah hukum yang krusial. Setelah merasakan pengalaman sebagai korban tindak pidana, ia harus mengalami viktimisasi lanjutan akibat adanya

${ }^{1}$ Kasi Intelijen Kejaksaan Negeri Bandung, alumnus Pascasarjana Fakultas Hukum Universitas Indonesia Tahun 2009. Alamat kontak: 
penolakan secara sistematis oleh sistem peradilan pidana. Penolakan tersebut terjadi karena adanya pandangan posisi korban telah diambil alih oleh negara, sehingga keterlibatan korban lebih jauh dalam proses peradilan untuk memperjuangkan hak-haknya dinilai akan membebani jalannya sistem yang ada. Selain itu juga dianggap akan berpengaruh pada efektivitas dan efisiensi kerja aparat penegak hukum.

Korban sebagai pihak yang menderita dan dirugikan akibat pelanggaran hukum pidana biasanya hanya dilibatkan sebatas pada memberikan kesaksian sebagai saksi korban. Akibatnya sering terjadi korban merasa tidak puas dengan tuntutan pidana yang diajukan oleh Jaksa Penuntut Umum dan/atau putusan yang dijatuhkan oleh Hakim karena dianggap tidak sesuai dengan nilai keadilan korban. Hal tersebut disebabkan karena sistem peradilan pidana diselenggarakan untuk mengadili pelaku tindak pidana, bukan untuk melayani kepentingan korban tindak pidana, karena tindak pidana merupakan tindakan pelakunya melawan negara. Keberadaan sistem peradilan pidana ditujukan untuk kepentingan negara dan masyarakat, bukan untuk kepentingan personal warga masyarakat. Hal ini menyebabkan kerugian akibat tindak pidana yang diderita oleh korban tindak pidana merupakan musibah yang harus ditanggung korban itu sendiri karena bukan merupakan fungsi sistem peradilan pidana untuk menanggungnya.

Menurut Muladi, dalam rangka konsep pengaturan terhadap perlindungan korban tindak pidana, hal pertama yang harus diperhatikan yakni esensi kerugian yang diderita korban. Esensi kerugian tersebut tidak hanya bersifat material atau penderitaan fisik saja tetapi juga yang bersifat psikologis. Hal ini dalam bentuk "trauma kehilangan kepercayaan terhadap masyarakat dan ketertiban umum". Simptom dari sindrom tersebut dapat berupa kegelisahan, rasa curiga, sinisme, depresi, kesepian dan perilaku penghindaran lainnya. ${ }^{2}$

Kerugian yang diderita oleh korban tindak pidana dapat dimintakan ganti rugi sebagai salah satu hak korban tindak pidana.United Nations Declaration on The Prosecution and Assistance of Crime Victims pada butir 4 Part IGeneral Principles telah menegaskan kewajiban tiap-tiap negara dalam pemenuhan hak-hak korban tindak pidana:

Reparation by the offender to the victim shall be an objective of the process justice. Such reparation may include (1) the return of stolen property, (2) monetary payment for loss, damages, personal injury and psychological trauma, (3) payment for suffering, and (4) service to the victim. Reparation should be encouraged by the correctional process. ${ }^{3}$

\footnotetext{
${ }^{2}$ Muladi, "Hak Asasi Manusia, Politik dan Sistem Peradilan Pidana", (Semarang: Badan Penerbit Universitas Diponegoro, 2002), hal. 177.
} 
Hal tersebut menunjukkan bahwa sebagai entitas internasional, PBB menghendaki ganti rugi oleh pelaku tindak pidana kepada korbannya seharusnya menjadi tujuan dari proses peradilan. Ganti rugi tersebut meliputi pengembalian harta benda yang dicuri, pembayaran sejumlah uang atas kehilangan, kerusakan, dan luka serta trauma psikis yang dialami korban, pembayaran untuk penderitaan dan bantuan kepada korban.

Salah satu bentuk ganti rugi terhadap korban tindak pidana yakni restitusi. Restitusi sesuai dengan Prinsip Pemulihan dalam Keadaan Semula (restutio in integrum) adalah suatu upaya bahwa korban kejahatan haruslah dikembalikan pada kondisi semula sebelum kejahatan terjadimeski didasari bahwa tidak akan mungkin korban kembali pada kondisi semula. Prinsip ini menegaskanbahwa bentuk pemulihan kepada korban haruslah selengkap mungkin dan mencakup berbagai aspekyang ditimbulkan dari akibat kejahatan. Dengan restitusi, maka korban dapat dipulihkan kebebasan, hak-hak hukum, status sosial, kehidupan keluarga dan kewarganegaraan, kembali ke tempat tinggalnya, pemulihan pekerjaannya, serta dipulihkan asetnya. Dalam praktik hampir di banyak negara konsep restitusi ini dikembangkan dandiberikan pula kepada korban kejahatan atas penderitaan mereka sebagai korban tindak pidana. Dalam konsep ini maka korban dan keluarganya harus mendapatkan ganti kerugian yang adil dan tepat dariorang bersalah atau pihak ketiga yang bertanggungjawab. Ganti kerugian ini akan mencakup pengembalian harta milik atau pembayaran atas kerusakan atau kerugian yang diderita, penggantian biaya-biaya yang timbul sebagai akibat jatuhnya korban, penyediaan jasa dan hak-hak pemulihan. ${ }^{4}$

Berdasarkan Pasal 1365 KUHPerdata,orang yang menderita kerugian yang disebabkan oleh perbuatan orang lain yang melawan hukum memiliki hak untuk menuntut ganti kerugian. Apabila orang tersebut menderita kerugian akibat suatu tindak pidana, untuk memudahkan orang tersebut, negara memberikan jalan untuk mendapat ganti kerugian tanpa harus melalui proses gugat perdata biasa dengan melalui penggabungan perkara gugatan ganti kerugian kepada perkara pidana yang diatur dalam KUHAP. Selanjutnya negara semakin memberikan ruang bagi para korban tindak pidana untuk mendapatkan haknya mendapatkan ganti rugi dengan jangkauan yang lebih luas denganmengeluarkan Undang-Undang Nomor 13 Tahun 2006 tentang Perlindungan Saksi dan Korban (selanjutnya disingkat UU No. 13 Tahun 2006) yang kemudian diganti dengan Undang-Undang Nomor 31 Tahun 2014 tentang Perubahan atas Undang-Undang Nomor 13 Tahun 2006 tentang Perlindungan Saksi dan Korban (selanjutnya disingkat UU No. 31 Tahun 2004).

${ }^{3}$ Romli Atmasasmita, Penulisan Karya Ilmiah tentang Masalah Santunan Terhadap Korban Tindak Pidana (Jakarta: Badan Pembinaan Hukum Nasional, Departemen Kehakiman, 1992), hal. 4.

\footnotetext{
${ }^{4}$ Supriyadi Widodo Eddyono, et.al, "Masukan Terhadap Perubahan UU No. 13 Tahun 2006 tentang Perlindungan Saksi dan Korban", (Jakarta: Koalisi Perlindungan Saksi dan Korban), hal. 16.
} 
Namun demikian, ternyata banyak masalah yang terjadi dalam implementasi ketentuan ganti rugi bagi korban tindak pidana, baikyang diatur dalam KUHAP maupun Undang-Undang Perlindungan Saksi dan Korban. Tulisan ini bertujuan untuk melakukan kajian terhadap beberapa permasalahan yang timbul sehubungan dengan ketentuan ganti rugi yang berupa restitusi bagi korban tindak pidana dan menawarkan suatu konsep mekanisme baru mengenai permohonan restitusi yang diajukan oleh korban tindak pidana, yang mengadopsi berbagai ketentuan tentang restitusi dari berbagai peraturan perundang-undangan yang dianggap ideal bagi korban.

\section{Penggabungan Perkara Gugatan Ganti Kerugian}

Apabila ketentuan dalam KUHAP dicermati dengan seksama, maka ganti kerugian dapat diberikan kepada korban tindak pidana dengan menilik pada Pasal 98 ayat (1) yang menyatakan bahwa jika suatu perbuatan yang menjadi dasar dakwaan di dalam suatu pemeriksaan perkara pidana oleh pengadilan negeri menimbulkan kerugian bagi orang lain, maka hakim ketua sidang atas permintaan orang itu dapat menetapkan untuk menggabungkan perkara gugatan ganti kerugian kepada perkara pidana itu.

Maksud dari "kerugian bagi orang lain" (subyeknya) tidak bersifat limitatif, yakni sesuai dengan ketentuan dalam hukum perdata, siapa saja yang menderita kerugian yang ditimbulkan oleh suatu tindak pidana, termasuk kerugian pihak korban (penjelasan Pasal 98 ayat (1) KUHAP), sedangkan jenis kerugian yang ditimbulkan dari suatu tindak pidana bersifat limitatif, yakni dibatasi pada kerugian yang bersifat materiil berupa biaya-biaya atau pengganti biaya yang telah dikeluarkan oleh pihak ketiga yang berkepentingan (Pasal 99 KUHAP) yang dikuatkan dengan yurisprudensi Mahkamah Agung RI Nomor 976 K/Pid/1988 tanggal 24 September 1991. Ketentuan tentang jenis kerugian ini tidak sesuai dengan aspirasi Pasal 101 KUHAP yaitu "ketentuan dari aturan hukum acara perdata berlaku bagi gugatan ganti kerugian." Hukum perdata tidak membatasi jenis dan jumlah kerugian yang dialami oleh pihak yang dirugikan (penggugat) apabila kerugian tersebut benar-benar sesuai dengan prinsip kausalitas sebagaimana diatur pada Pasal 1365 KUHPerdata.

Kemungkinan gugatan pihak ketiga atau korban tindak pidana yang dapat digabungkan dangan perkara pidanamerupakan bentuk baru yang diperkenalkan dalam hukum acara pidana di Indonesia. Pemeriksaan dan putusan dikabulkan atau tidaknya permohonan ganti kerugian bersifat asesoir, artinya putusan dikabulkan atau ditolaknya permohonan ganti kerugian bergantung kepada putusan perkara pokok, yakni perbuatan pidana yang didakwakan oleh Jaksa Penuntut Umum. Putusan ganti kerugian kepada pihak ketiga baru dapat dieksekusi jika putusan pokoknya telah memiliki kekuatan hukum yang tetap.

Akan tetapi ternyata terdapat beberapa kekurangan dari KUHAP menyangkut pemberian ganti rugi ini.Pertama, prosedur pengajuannya yang tidak sederhana karena pengajuan ganti kerugian hanya dapat dilakukan melalui gugatanganti kerugian yang digabungkan dengan pemeriksaan pokok 
perkara pidananya. Di samping itu, dalam prosesnya yang harus aktif yakni korban tindak pidana. Ia harus sering berhubungan dengan aparat penegak hukum untuk memastikan proses pengajuan gugatan ganti ruginya akan diakomodasi oleh penuntut umum dalam tuntutannya. Hal ini tentunya akan menghabiskan waktu dan uang dari korban tindak pidana. Kedua, bentuk ganti rugi yang diberikan pun ternyata hanya terhadap kerugian yang sifatnya materiil. Putusan hakim hanya terbatas tentang pengabulan yang menetapkan penggantian biaya yang telah dikeluarkan oleh pihak yang dirugikan. Hal ini berarti besarnya ganti kerugian hanyalah sebesar jumlah kerugian nyata atau kerugian materiil saja. Di luar kerugian nyata, seperti kerugian yang bersifat immateriil, tidak dapat diajukan dalam penggabungan perkara. Seandainya ganti kerugian yang immateriil ada diajukan oleh pihak yang dirugikan, hakim harus menyatakan gugatan tersebut tidak dapat diterima (niet onvankelijke). ${ }^{5}$ Pengajuan ganti rugi immateriil hanya dapat diajukan dengan prosedur gugatan perdata yang prosesnya lama dan berbelit-belit.

\section{Pengajuan Permohonan Restitusi bagi Korban Tindak Pidana}

Selain KUHAP, peraturan perundang-undanganyang mengatur mengenai restitusi bagi korban tindak pidana sebenarnya telah ada sebelum UU No. 13 Tahun 2006 terbentuk. Akan tetapi, ketentuan tersebut masih terbatas untuk korban dari suatu tindak pidana tertentu, yakni korban pelanggaran hak asasi manusia yang berat ${ }^{6}$ dan korban tindak pidana terorisme.

Dalam UU No. 13 Tahun 2006, ketentuan mengenai restitusi hanya diatur dalam satu pasal sebagai berikut:

Pasal 7

(1) Korban melalui LPSK berhak mengajukan ke pengadilan berupa:

a. hak atas kompensasi dalam kasus pelanggaran hak asasi manusia yang berat;

b. hak atas restitusi atau ganti kerugian yang menjadi tanggung jawab pelaku tindak pidana.

(2) Keputusan mengenai kompensasi dan restitusi diberikan oleh pengadilan.

5 M. Yahya Harahap, "Pembahasan Permasalahan dan Penerapan KUHAP Jilid II", (Jakarta: Sarana Bakti Semesta, 1985), hal. 604.

${ }^{6}$ Undang Nomor 26 Tahun 2000 tentang Pengadilan HAM dan Peraturan Pemerintah Nomor 3 Tahun 2002 tentang Pemberian Kompensasi, Restitusi, dan Rehabilitasi Terhadap Korban Pelanggaran HAM yang Berat.

7 Undang-Undang Nomor 15 Tahun 2003 tentang Penetapan Peraturan Pemerintah Pengganti Undang-Undang Nomor 1 Tahun 2002 tentang Pemberantasan Tindak Pidana Terorisme. 


\section{(3) Ketentuan lebih lanjut mengenai pemberian kompensasi dan restitusi diatur denganPeraturan Pemerintah.}

Minimnya aturan mengenai restitusi ini tentunya akan menyulitkan korban tindak pidana yang akan mengajukan permohonan restitusi. Pertama, korban tidak mengetahui dengan pasti kerugian-kerugian yang dapat dimohonkan restitusi. Kedua, korban tidak mengetahui waktu pengajuan permohonan restitusi tersebut: apakah korban dapat langsung mengajukan permohonan restitusi tersebut ke LPSK sesaat setelah terjadinya tindak pidana, atau sebelum penuntut umum mengajukan tuntutan pidana, atau sebelum hakim menjatuhkan putusan? Ketiga, korban tidak mengetahui mekanisme yang dapat ditempuh apabila pelaku tindak pidana tidak mampu atau tidak mau untuk membayar ganti rugi dimohonkan oleh korban.Keempat, korban juga tidak mengetahui jangka waktu pembayaran restitusi dari pelaku tindak pidana kepada dirinyasejak putusan hakim yang mengharuskan pelaku untuk membayar restitusi pada korban berkekuatan hukum tetap.

Berbagai ketidak jelasan tersebut baru dapat terjawab dua tahun kemudian ketika pemerintah mengeluarkan Peraturan Pemerintah Nomor 44 Tahun 2008 tentang Pemberian Kompensasi, Restitusi, dan Bantuan kepada Saksi dan Korban (selanjutnya disingkat PPtuNo. 44 Tahun 2008). Dalam PP tersebut dinyatakan bahwa restitusi adalah ganti kerugian yang diberikan kepada korban atau keluarganya oleh pelaku atau pihakketiga, dapat berupa pengembalian harta milik, pembayaran ganti kerugian untuk kehilangan ataupenderitaan, atau penggantian biaya untuk tindakan tertentu (Pasal 1 angka 5). Permohonan untuk memperoleh restitusi diajukan oleh korban, keluarga, atau kuasanya dengan surat kuasa khusus secara tertulis kepada pengadilan melalui LPSK (Pasal 20 ayat (2) dan (3)). Pengajuan permohonan tersebut dapat dilakukan sebelum atau setelah pelaku dinyatakan bersalah berdasarkanputusan pengadilan yang telah memperoleh kekuatan hukum tetap (Pasal 21).Pelaku tindak pidana dan/atau pihak ketiga melaksanakan penetapan atau putusan pengadilan dalam jangka waktu paling lambat 30 (tiga puluh) hari sejak menerima salinan penetapan atau putusan pengadilan (Pasal 31). Apabila pelaksanaan pemberian restitusi melampaui jangka waktu 30 hari, maka setelah korban melaporkan hal tersebut kepada pengadilan dan LPSK, pengadilan segera memerintahkan pelaku tindak pidana untuk melaksanakan pemberian restitusi, dalam jangka waktu paling lambat 14(empat belas) hari terhitung sejak tanggal perintah diterima (Pasal 32).

Akan tetapi, aturan yang spesifik tentang restitusi yang baru diatur di dalam PP No. 44 Tahun 2008 ternyata menimbulkan masalah dalam praktiknya. Banyak hakim dan jaksa yang cenderung lebih memilih menggunakan penggabungan gugatan ganti kerugian sebagaimana diatur dalam Pasal 98 KUHAP karena hukum acaranya dianggap lebih pasti, kuat, dan fleksibel daripada mekanisme restitusi dalam UU No. 13 Tahun 2006 yang justru dijabarkan dalam PP No. 44 Tahun 2008. Banyak aparat penegak hukum yang menganggap pengaturan mekanisme restitusi di dalam PP No. 44 Tahun 2008 tersebut tidak sejajar dengan pengaturan dalam KUHAP sehingga tidak 
memiliki kekuatan sebagaimana berada di bawah KUHAP. Oleh karena itu, mekanisme restitusi yang seharusnya digunakan yakni mekanisme yang diatur oleh Pasal 98 KUHAP. ${ }^{8}$

Selanjutnya, karena pada akhirnya mekanisme Pasal 98 KUHAP yang digunakan, maka terkait dengan ruang lingkup restitusi dalam UU No. 13 Tahun 2006 menjadi tidak aplikatif. Ketentuan tentang restitusi dalam UU No. 13 Tahun 2006 memiliki jangkauan yang lebih, yakni dapat berupa pengembalian harta milik, pembayaran ganti kerugian untuk kehilangan atau penderitaan, atau penggantian biaya untuk tindakan tertentu, sedangkan ketentuan tentang ganti kerugian dalam KUHAP hanya terfokus pada kerugian yang nyata akibat tidak pidana. Hal ini menyebabkan dalam praktiknya, hanya kerugian-kerugian materil yang dapat periksa oleh hakim yang bersangkutan. Untuk tuntutan ganti rugi atas kehilangan bagi korban dianggap bersifat immateril, sehingga untuk memperoleh ganti rugi tersebut, korban harus menggunakan mekanisme hukum perdata. ${ }^{9}$

Pada 17 Oktober 2014, kurang lebih 8 (delapan) tahun sejak berlakunya UU No. 13 Tahun 2006, Undang-Undang Nomor 31 Tahun 2014 tentang Perubahan atas Undang-Undang Nomor 13 Tahun 2006 tentang Perlindungan Saksi dan Korban (selanjutnya disingkat UU No. 31 Tahun 2014) disahkan. Dalam penjelasan umumnya dinyatakan bahwa dengan adanya perkembangan hukum di masyarakat, maka tampaklah beberapa kelemahan yang cukup signifikan dalam pelaksanaan UU No. 13 Tahun 2006 sehingga diperlukan perubahan pengaturan tentang perlindungan saksi dan korban dalam UndangUndang tentang Perubahan atas Undang-Undang Nomor 13 Tahun 2006 tentang Perlindungan Saksi dan Korban. Sehubungan dengan perubahan pengaturan tersebut, dalam hal restitusi bagi korban tindak pidana, UU No. 31 Tahun 2014 akhirnya memasukkan ketentuan-ketentuan yang sebelumnya diatur dalam PP No. 44 Tahun 2008. Ketentuan-ketentuan tersebut dituangkan dalam satu pasal berikut ini:

\section{Pasal 7A}

(1) Korbantindak pidana berhak memperoleh restitusi berupa:

a. ganti kerugian atas kehilangan kekayaan atau penghasilan;

b. ganti kerugian yang ditimbulkan akibat penderitaan yang berkaitan langsung sebagai akibat tindak pidana; dan/atau

c. penggantian biaya perawatan medis dan/atau psikologis.

(2) Tindak pidana sebagaimana dimaksud pada ayat (1) ditetapkan dengan Keputusan LPSK.

${ }^{8}$ Naskah Akademik RUU LPSK (Rancangan Undang-undang Lembaga Perlindungan Saksi dan Korban), (Jakarta: 2014), hal. 25.

${ }^{9}$ Ibid. 
(3) Pengajuan permohonan restitusi dapat dilakukan sebelum atau setelah putusan pengadilan yang telah memperoleh kekuatan hukum tetap melalui LPSK.

(4) Dalam hal permohonan restitusi diajukan sebelum putusan pengadilan yang telah memperoleh kekuatan hukum tetap, LPSK dapat mengajukan restitusi kepada penuntut umum untuk dimuat dalam tuntutannya.

(5) Dalam hal permohonan restitusi diajukan setelahputusan pengadilan yang telah memperoleh kekuatan hukum tetap, LPSK dapat mengajukan restitusi kepada pengadilan untuk mendapat penetapan.

(6) Dalam hal korban tindak pidana meninggal dunia, restitusi diberikan kepada keluarga korban yang merupakan ahli waris korban. ${ }^{10}$

Apabila dicermati dengan seksama, ketentuan tentang restitusi ini masih mengandung sejumlah masalah. UU No. 31 Tahun 2014 memang sudah mengakomodasi beberapa ketentuan tentang mekanisme restitusi bagi korban tindak pidana yang tadinya diatur dalam PP No. 44 Tahun 2008 sehingga dapat dapat dikatakan bahwa kini ketentuan tersebut sejajar dengan KUHAP. Dengan demikian, para aparat penegak hukum kini dapat "dipaksa" untuk menggunakan mekanisme restitusi yang diatur dalam UU No. 31 Tahun 2014 yang jangkauan restitusinya lebih banyak daripada KUHAP karena ketentuan mekanisme restitusi tersebut kini memiliki kekuatan sebagaimana bila diatur dalam KUHAP. Akan tetapi, dalam undang-undang tersebut ada sebuah ketentuan baru yang justru membatasi pemberian hak restitusi bagi korban tindak pidana. Pasal 7A ayat (2) menyatakan bahwa tindak pidana sebagaimana dimaksud dalam ayat (1) ditetapkan dengan Keputusan LPSK. Hal ini berarti hak memperoleh restitusi tidak dapat berlaku untuk semua korban tindak pidana. Hak tersebut hanya berlaku bagi korban tindak pidana tertentu yang penetapannya pun tidak jelas karena hanya dinyatakan "ditetapkan dengan Keputusan LPSK". Di bagian penjelasan, ayat ini dinyatakan cukup jelas, padahal tidak ada kejelasan tentang ayat ini mengingat tidak ada ketentuan seperti itu dalam UU No. 13 Tahun 2006 dan PP No. 44 Tahun 2008. Yang menjadi pertanyaan kemudian yakni apakah alasan dari adanya pembatasan tersebut? Apakah yang menjadi dasar bagi LPSK untuk menentukan korban dari tindak pidana apa yang berhak memperoleh restitusi? Bukankah pembatasan tersebut justru akan membatasi akses semua korban tindak pidana untuk mendapatkan hak restitusinya? Hal tersebut justru berbanding terbalik dengan tujuan pendirian LPSK untuk melindungi saksi dan korban tindak pidana di Indonesia. Lebih lanjut dapat dikatakan bahwa hal tersebut tentu merupakan kemunduran bagi upaya perlindungan bagi korban tindak pidana.

\footnotetext{
${ }^{10}$ Indonesia, Undang-Undang Perubahan Atas Undang-Undang Nomor 13 Tahun 2006 TentangPerlindungan Saksi dan Korban, UU No. 31 Tahun 2014, LN No. 293 Tahun 2014, TLN No. 5602, Pasal 7A.
} 
Dengan pengaturan yang justru membatasi korban tindak pidana mendapatkan haknya atas restitusi, tentunya akan lebih baik bagi korban tindak pidana apabila para aparat penegak hukum menggunakan mekanisme restitusi yang diatur dalam KUHAP karena semua korban tindak pidana dapat memperoleh kesempatan yang sama untuk mendapatkan haknya atas restitusi.

\section{Tawaran Mekanisme Baru bagi Korban Tindak Pidana untuk Mendapatkan Restitusi}

Sebagaimana telah dijelaskan sebelumnya, dalam hal perlindungan bagi korban, khususnya hak korban untuk mendapatkan restitusi dari pelaku tindak pidana, KUHAP telah menyediakan mekanisme penggabungan gugatan ganti kerugian dalam Pasal 98-101. Namun dalam praktiknya, hal ini jarang sekali diterapkan karena kendala dalam hal korban terlambat atau tidak melaporkan kepada jaksa penuntut umum tentang permintaan gugatan ganti kerugian sehingga pada saat jaksa penuntut umum membacakan tuntutannya, tuntutan tersebut tidak memuat tentang gugatan ganti kerugian. Selain itu, yang menjadi kendala yakni lamanya prosedur pembayaran gugatan ganti kerugian dari pemerintah kepada korban, walaupun dalam putusan pengadilan sudah ditetapkan bahwa terhadap korban perlu diberikan ganti kerugian, dan biasanya hanya diterapkan dalam beberapa jenis tindak pidana (misalnya kecelakaan lalu lintas dan penganiayaan). KUHAP sebenarnya telah meletakkan landasan pikir dan konsep terhadap perlindungan korban dalam proses di persidangan namun demikian tentunya pengaturan tersebut belum cukup. Keberadaan UndangUndang Perlindungan Saksi dan Korban secara mendasar telah memberikan perubahan dalam cara berpikir penegak hukum dan masyarakat lainnya, bahwa korban juga memiliki hak dan kepentingan yang harus dijamin dan dilindungi oleh undang-undang dan wajib dipenuhi dalam penegakan hukum. Dalam kerangka melihat keterkaitan posisi Undang-Undang Perlindungan Saksi dan Korban dengan KUHAP, jelaslah bahwa kehadiran undang-undang ini untuk melengkapi aturan-aturan perlindungan saksi dan korban yang belum diatur dalam KUHAP. Kebutuhan perubahan Undang-Undang Perlindungan Saksi dan Korban adalah menyusun rumusan-rumusan pasal yang secara rinci dan operasional dapat diterapkan dalam hukum acara pidana dalam aspek perlindungan saksi dan korban pada tahap penyelidikan-penyidikan hingga putusan hakim dan eksekusi oleh jaksa serta pengaturan mengenai permohonan restitusi yang harus diharmonisasikan dengan pengaturan mengenai penggabungan ganti rugi sebagaimana yang diatur dalam pasal 98 KUHAP. ${ }^{11}$

Akan tetapi, sebagaimana yang telah dipaparkan sebelumnya, UU No. 31 Tahun 2014 justru telah mengebiri hak korban tindak pidana untuk mendapatkan restitusi dengan memberikan pembatasan untuk tindak pidana tertentu yang ditentukan oleh LPSK. Dengan demikian, akanlah sulit untuk melakukan harmonisasi antara pengaturan mengenai permohonan restitusi

\footnotetext{
${ }^{11}$ Naskah Akademik RUU LPSK, Op. Cit., hal. 32-33.
} 
menurut UU No. 31 Tahun 2014 dengan pengaturan mengenai penggabungan ganti kerugian menurut KUHAP. Hal ini disebabkan jangkauan mekanisme restitusi yang ditawarkan oleh KUHAP menjadi lebih luas karena tidak terbatas pada korban dari suatu tindak pidana tertentu sehingga tentu akan lebih dipilih oleh korban tindak pidana dan aparat penegak hukum.

Penulis berpendapat, daripada melakukan harmonisasi antara ketentuan permohonan restitusi dalam UU No. 31 Tahun 2014 dengan ketentuan penggabungan ganti kerugian dalam KUHAP, akan lebih baik apabila ketentuan permohonan restitusi yang ada dalam UU No. 31 Tahun 2014 diakomodasi oleh KUHAP karena sebagai hukum formil, KUHAP menjadi pedoman dan rujukan utama yang dipilih oleh aparat penegak hukum dalam melaksanakan tugasnya dibanding ketentuan yang ada di luar KUHAP. Disamping itu, dengan diatur dalam KUHAP, maka ketentuan tentang restitusi akan lebih luas cakupan dan ruang lingkupnya, tidak terbatas pada tindak pidana tertentu saja mengingat restitusi diatursecara berbeda-beda dalam berbagai peraturan perundang-undangan. Apabila ketentuan mengenai restitusi bagi korban tindak pidana hanya diatur dalam KUHAP, maka akan ada persamaanmekanisme implementasinya oleh aparat penegak hukum.

Akan tetapi, KUHAP haruslah memasukkan ketentuan tentang daya paksa bagi pelaku tindak pidana untuk membayar ganti rugi kepada korban tindak pidana. Dengan tidak diaturnya tentang daya paksa bagi pelaku tindak pidana untuk membayar ganti rugi kepada korban, maka apabila pelaku tindak pidana tidak mampu atau tidak mau membayar restitusi kepada korban, hal tersebut tidak berakibat hukum dan menimbulkan implikasi apa pun bagi pelaku. Akan tetapi, di lain pihak, hal tersebut tentunyaakan menghalangi korban tindak pidana untuk memperoleh restitusi. Oleh karena itu, perubahan KUHAP pun dapat mengakomodasi ketentuan tentang daya paksa pembayaran restitusi yang diatur dalam Undang-Undang Nomor 21 Tahun 2007 tentang Pemberantasan Tindak Pidana Perdagangan Orang (selanjutnya disingkat UU No. 21 Tahun 2007) sebagai berikut:

Pasal 50

(1) Dalam hal pelaksanaan pemberian restitusi kepada pihak korban tidak dipenuhisampai melampaui batas waktu sebagaimana dimaksud dalam Pasal 48 ayat $(6)^{12}$, korban atau ahli warisnya memberitahukan hal tersebut kepada pengadilan.

(2) Pengadilan sebagaimana dimaksud pada ayat (1) memberikan surat peringatansecara tertulis kepada pemberi restitusi, untuk segera memenuhi kewajibanmemberikan restitusi kepada korban atau ahli warisnya.

\footnotetext{
12 Pasal 48 ayat (6) UU No. 21 Tahun 2007 menyatakan bahwa pemberian restitusi dilakukan dalam 14 (empat belas) hari terhitung sejakdiberitahukannya putusan yang telah memperoleh kekuatan hukum tetap.
} 
(3) Dalam hal surat peringatan sebagaimana dimaksud pada ayat (2) tidak dilaksanakandalam waktu 14 (empat belas) hari, pengadilan memerintahkan penuntut umum untukmenyita harta kekayaan terpidana dan melelang harta tersebut untuk pembayaranrestitusi.

(4) Jika pelaku tidak mampu membayar restitusi, maka pelaku dikenai pidana kurunganpengganti paling lama 1 (satu) tahun. $^{13}$

Ketentuan tersebut sebenarnya hanya menjawab tentang daya paksa apabila pelaku tindak pidana tidak mampu untuk membayar ganti rugi dimohonkan oleh korban tindak pidana, tetapi tidak menjawab apabila pelaku tindak pidana tidak mau untuk membayar ganti rugi. Untuk itu, Rancangan Undang-Undang Hukum Acara Pidana Tahun 2012 (selanjutnya disingkat RKUHAP Tahun 2012) sebenarnya telah memasukkan ketentuan tentang daya paksa bagi pelaku tindak pidana sebagai berikut:

Pasal $133^{14}$

(1) Apabila terdakwa dijatuhi pidana dan terdapat korban yangmenderita kerugian materiel akibat tindak pidana yang dilakukanoleh terdakwa, hakim mengharuskan terpidana membayar gantikerugian kepada korban yang besarnya ditentukan dalamputusannya.

(2) Apabila terpidana tidak membayar ganti kerugian sebagaimanadimaksud pada ayat (1), harta benda terpidana disita dan dilelanguntuk membayar ganti kerugian kepada korban.

(3) Apabila terpidana berupaya menghindar untuk membayarkompensasi kepada korban, terpidana tidak berhak mendapatkanpengurangan masa pidana dan tidak mendapatkan pembebasanbersyarat.

(4) Dalam penjatuhan pidana bersyarat dapat ditentukan syarat khususberupa kewajiban terpidana untuk membayar ganti kerugian kepadakorban.

(5) Ketentuan lebih lanjut mengenai syarat dan tata cara penyitaan danpelelangan sebagaimana dimaksud pada ayat (2) diatur denganPeraturan Pemerintah. ${ }^{15}$

${ }^{13}$ Indonesia, Undang-Undang Pemberantasan Tindak Pidana Perdagangan Orang, UU No. 21 Tahun 2007, LN No. 58 Tahun 2007, TLN No. 4720, ps.50.

${ }^{14}$ Penjelasan Pasal 133 berbunyi:

Terpidana yang mampu membayar ganti kerugian tidakpantas mendapatkan pidana yang lebih ringandibandingkan dengan orang yang tidak mampu sebab iamemiliki uang untuk membayar kompensasi. Ketentuan ini dimaksudkan agar terpidana yang memiliki kemampuan membayar kompensasi menghindari pembayaran ganti kerugian. 
Ketentuan tentang daya paksa pembayaran ganti rugi tersebut jelas berbeda dengan ketentuan daya paksa pembayaran restitusi yang diatur dalam UU No. 21 Tahun 2007 karena menekankan pada daya paksa pembayaran ganti rugi bagi pelaku tindak pidana apabila pelaku berupaya menghindar (tidak mau) untuk membayar ganti rugi kepada korban. Ganti kerugian yang dimaksudkan dalam RKUHAP Tahun 2012 tersebut pun berupa kompensasi, bukan restitusi, meskipun masih banyak perdebatan yang muncul tentang definisi yang benar mengenai kedua istilah ganti kerugian tersebut. Akan tetapi, ketentuan dalam Pasal 133 RKUHAP Tahun 2012 tersebut, khususnya ayat (3), dapat dijadikan acuan untuk membuat ketentuan mengenai daya paksa pembayaran restitusi apabila pelaku tindak pidana tidak mau untuk membayar restitusi. Hal ini diperlukan agar KUHAP yang baru dapat dilengkapi dengan aturan-aturan perlindungan korban, khususnya mengenai restitusi, yang belum diatur dalam Undang-Undang Nomor 8 Tahun 1981 tentang Kitab Undangundang Hukum Acara Pidana. Dengan kata lain, perubahanKUHAP dalam hal restitusi dapat terlihat dengan jelas dari susunan rumusan-rumusan pasal yang secara rinci dan operasional, yang dapat diterapkan dalam hukum acara pidana dalam aspek perlindungan korban, mulai dari tahap penyelidikan-penyidikan hingga eksekusi putusan atau penetapan hakim.

Perlu ditambahkan, Pasal 7 ayat (1) UU No. 13 Tahun 2006 menyebutkan bahwa korban melalui LPSK berhak mengajukan ke pengadilan berupa hak atas restitusi. Ketentuan ini memunculkan mekanisme baru dalam prosedur pengajuan hak atas restitusi yakni terlibatnya LPSK dalam prosedur pengajuan. Pengaturan tersebut menunjukkan dua penafsiran. Pertama, tuntutan ganti kerugian (restitusi) hanya bisa diajukan oleh korban melalui LPSK. Kedua, korban dapat mengajukan ganti kerugian melalui LPSK dan dapat juga mengajukan ganti kerugian dengan prosedur lainnya, misalnya KUHAP. Untuk memastikan prosedur baku, perlu keselarasan dengan regulasi lainnya, misalnya dengan KUHAP. Jika tidak ada keselarasan dalam prosedur pengajuan hak atas restitusi, maka kemungkinan akan menimbulkan kebingungan bagi korban tentang mekanisme yang akan digunakan dalam mengajukan tuntuan restitusi. ${ }^{16}$

Pasal 7A ayat (4) UU No. 31 Tahun 2014 menyebutkan bahwa dalam hal permohonan restitusi diajukan sebelum putusan pengadilan yang telah memperoleh kekuatan hukum tetap, LPSK dapat mengajukan restitusi kepada penuntut umum untuk dimuat dalam tuntutannya. Hal ini berarti untuk mendapatkan restitusi yang pengajuan permohonannya dilakukan sebelum putusan, korban harus melibatkan dua pihak yakni LPSK dan Jaksa Penuntut Umum.

Sebagai gambaran -mengingat untuk UU No. 31 Tahun 2014 tidak mengatur secara rinci tentang prosedur pengajuan permohonan restitusi melalui

\footnotetext{
${ }^{15}$ Rancangan Undang-Undang Hukum Acara Pidana Tahun 2012, ps. 133.

${ }^{16}$ Wahyu Wagiman dan Zainal Abidin, "Praktik Kompensasi dan Restitusi di Indonesia: Sebuah Kajian Awal”, (Jakarta: Indonesia Corruption Watch, 2007), hal. 12.
} 
LPSK- dalam PP No. 44 Tahun 2008, prosedur yang harus dilalui oleh korban ketika mengajukan permohonan restitusi melalui LPSK diatur sebagai berikut:

\section{Pasal 23}

(1) LPSK memeriksa kelengkapan permohonan restitusi sebagaimana dimaksud dalam Pasal 22.

(2) Dalam hal terdapat kekuranglengkapan permohonan sebagaimana dimaksud pada ayat (1), LPSKmemberitahukan secara tertulis kepada pemohon untuk melengkapi permohonan.

(3) Pemohon dalam jangka waktu 14 (empat belas) hari terhitung sejak tanggal pemohon menerimapemberitahuan dari LPSK, wajib melengkapi berkas permohonan.

(4) Dalam hal permohonan sebagaimana dimaksud pada ayat (2) tidak dilengkapi oleh pemohon, makapemohon dianggap mencabut permohonannya.

Pasal 24

Dalam hal berkas permohonan sebagaimana dimaksud dalam Pasal 22 dinyatakanlengkap, LPSK segeramelakukan pemeriksaan substantif.

Pasal 25

(1) Untuk keperluan pemeriksaan permohonan restitusi sebagaimana dimaksud dalam Pasal 24, LPSK dapat memanggil korban, keluarga, atau kuasanya, dan pelaku tindak pidana untuk memberi keterangan.

(2) Dalam hal pembayaran restitusi dilakukan oleh pihak ketiga, pelaku tindak pidana dalam memberikan keterangan kepada LPSK sebagaimana dimaksud pada ayat (1) wajib menghadirkan pihak ketiga tersebut.

Pasal 26

(1) Dalam hal korban, keluarga, atau kuasanya tidak hadir untuk memberikan keterangan 3 (tiga) kali berturutturuttanpa alasan yang sah, permohonan yang diajukan dianggap ditarik kembali.

(2) LPSK memberitahukan penarikan kembali permohonan sebagaimana dimaksud pada ayat (1) kepadapemohon.

\section{Pasal 27}

1. Hasil pemeriksaan permohonan restitusi sebagaimana dimaksud dalam Pasal 24 dan Pasal 25 ditetapkan dengan keputusan LPSK, disertai dengan pertimbangannya.

2. Dalam pertimbangan LPSK sebagaimana dimaksud pada ayat (1) disertai rekomendasi untuk mengabulkan permohonan atau menolak permohonan restitusi. 
Pasal 28

(1) Dalam hal permohonan restitusi diajukan berdasarkan putusan pengadilan yang telah memperolehkekuatan hukum tetap dan pelaku tindak pidana dinyatakan bersalah, LPSK menyampaikan permohonantersebut beserta keputusan dan pertimbangannya sebagaimana dimaksud dalam Pasal 27 kepadapengadilan yang berwenang.

(2) Dalam hal permohonan restitusi diajukan sebelum tuntutan dibacakan, LPSK menyampaikan permohonantersebut beserta keputusan dan pertimbangannya kepada penuntut umum.

(3) Penuntut umum sebagaimana dimaksud pada ayat (2) dalam tuntutannya mencantumkan permohonan restitusi beserta Keputusan LPSK dan pertimbangannya.

(4) Salinan surat pengantar penyampaian berkas permohonan dan pertimbangan sebagaimana dimaksud padaayat (1) dan ayat (2), disampaikan kepada korban,keluarga atau kuasanya, dan kepada pelaku tindakpidana dan/atau pihak ketiga. $^{17}$

Dari aturan Pasal 23-28 tersebut jelaslah bahwa korban tindak pidana harus melalui serangkaian prosedur yang memakan waktu cukup lama apabila korban tersebut mengajukan permohonan restitusi melalui LPSK sehingga prosedur tersebut jelas bukanlah prosedur yang praktis bagi korban. Korban tindak pidana harus menunggu kepastian terlebih dahulu dari LPSK perihal diterima atau ditolaknya permohonan restitusi tersebut. Bila permohonan restitusi itu diterima oleh LPSK, barulah permohonan tersebut diajukan ke pengadilan (bila permohonan restitusi diajukan berdasarkan putusan pengadilan yang telah memperolehkekuatan hukum tetap dan pelaku tindak pidana dinyatakan bersalah) atau ke Jaksa Penuntut Umum (bila permohonan restitusi diajukan sebelum tuntutan dibacakan). Karena itulah akan lebih mudah dan cepat bagi korban tindak pidana apabila untuk permohonan restitusi yang diajukan sebelum tuntutan dibacakan, korban dapat mengajukan permohonannya langsung ke Jaksa Penuntut Umum. Untuk itu, dalam perubahan KUHAP perlu adanya ketentuan mengenai mekanisme pengajuan permohonan restitusi yang tentunya akan berbeda dengan mekanisme penggabungan perkara gugatan ganti kerugian sebagaimana diatur dalam Pasal 98-101 KUHAP. Dalam perubahan KUHAP, mekanisme pengajuan

${ }^{17}$ Indonesia, Peraturan Pemerintah Pemberian Kompensasi, Restitusi, dan Bantuan kepada Saksi dan Korban, PP No. 44 Tahun 2008, LN No. 84 Tahun 2008, TLN No. 4860, Pasal 23-28. 
permohonan restitusi tersebut dapat mengadopsi ketentuan dalam Penjelasan Pasal 48 ayat (1) UU No. 21 Tahun 2007:

Dalam ketentuan ini, mekanisme pengajuan restitusi dilaksanakan sejak korbanmelaporkan kasus yang dialaminya kepada Kepolisian Negara Republik Indonesiasetempat dan ditangani oleh penyidik bersamaan dengan penanganan tindak pidana yangdilakukan. Penuntut umum memberitahukan kepada korban tentang haknya untukmengajukan restitusi, selanjutnya penuntut umum menyampaikan jumlah kerugian yangdiderita korban akibat tindak pidana perdagangan orang bersamaan dengan tuntutan.Mekanisme ini tidak menghilangkan hak korban untuk mengajukan sendiri gugatan ataskerugiannya. $^{18}$

Akan tetapi, dalam perubahan KUHAP, konsep mekanisme pengajuan permohonan restitusi tersebut akan direvisi menjadi sebagai berikut:

Mekanisme pengajuan restitusi dilaksanakan sejak korban melaporkan tindak pidana yang dialaminya kepada Kepolisian Negara Republik Indonesia setempat dan ditangani oleh penyidik bersamaan dengan penanganan tindak pidana yang dilakukan. Penyidik memberitahukan kepada korban tentang haknya untuk mengajukan restitusi, selanjutnya penyidik mencantumkan uraian tentang kerugian yang nyata-nyata diderita oleh korban ${ }^{19}$ dalam berkas perkara. Setelah berkas perkara dilimpahkan oleh penyidik kepada Penuntut Umum, kemudian Jaksa Penuntut Umum meneliti berkas perkara. Apabila Jaksa Penuntut Umum menemukan bahwa penyidik tidak mencantumkan uraian tentang kerugian yang nyatanyata diderita oleh korban, maka Jaksa Penuntut Umum akan memberikan petunjuk kepada penyidik untuk memperbaiki berkas perkara dengan mencantumkan uraian tersebut. Selanjutnya Jaksa Penuntut Umum memanggil korban guna memastikan korban memiliki bukti kerugian yang nyata-nyata diderita olehnya yang dibuat ataudisahkan olehpejabat yang berwenang. Setelah itu, JaksaPenuntutUmumyangditunjuk untuk menangani perkara tersebut memberitahukan kepada korban untuk membuat permohonan restitusi, yang akan disampaikan oleh Jaksa Penuntut Umum bersamaan dengan pembacaan surat tuntutan.

\footnotetext{
${ }^{18}$ Indonesia, Undang-Undang Pemberantasan Tindak Pidana Perdagangan Orang, Op. Cit., Pasal 48.

${ }^{19}$ Kerugian yang dapat dimintakan restitusi yakni kerugian materiil yang nyata dialami oleh korban tindak pidana dan kerugian lain yang pantas. Yang dimaksud dengan kerugian lain yang pantas adalah kerugian yang dialami oleh ahli waris atau orang yang menggantungkan penghidupan dari korban yang bisa diukur dan dihitung. Misalnya nafkah yang tidak bisa dinikmati oleh ahli waris dari korban yang menjadi tulang punggung keluarga yang meninggal dalam suatu kecelakaan lalu lintas. Kerugian ahli waris tersebut dapat dihitung kepantasanya menyangkut jumlah dan jangka waktu pemberian ganti kerugiannya.
} 
Konsep mekanisme pengajuan permohonan restitusi tersebut secara langsung akan meniadakan ketentuan Pasal 7A ayat (3) UU No. 31 Tahun 2014 yang menyatakan bahwa pengajuan permohonan restitusi dapat dilakukan sebelum atau setelah putusan pengadilan yang telah memperoleh kekuatan hukum tetap melalui LPSK. Selain menggantikan peran LPSK dengan Kejaksaan, konsep ini juga hanya mengatur tentang permohonan restitusi yang diajukan oleh korban tindak pidana sebelum tuntutan dibacakan oleh Jaksa Penuntut Umum. Hal tersebut untuk menghindari ketidakpastian hukum dan memberikan rasa aman bagi korban tindak pidana akan terpenuhinya hakhaknya sebagai korban. Hal ini dimungkinkan karena apabila pelaku tindak pidana tidak mau atau tidak mampu membayar restitusi yang jumlahnya telah diputuskan oleh hakim, maka Jaksa Penuntut Umum dapat memaksa pelaku dengan cara menyita dan melelang harta benda pelaku untuk membayar restitusi bagi korban tindak pidana. Selain itu, jika pelaku tidak mampu membayar restitusi, maka pelaku akan dikenai pidana kurunganpengganti. Sedangkan apabila pelaku berupaya menghindar untuk membayarkompensasi kepada korban, maka pelakunantinya tidak berhak mendapatkanpengurangan masa pidana dan tidak mendapatkan pembebasanbersyarat. ${ }^{20}$

Dalam hal peniadaan ketentuan mengenai permohonan restitusi yang diajukan setelah putusan pengadilan yang telah memperoleh kekuatan hukum tetap, hal tersebut dilakukan dalam rangka menghindari masalah dalam pelaksanaan penetapan hakim. Di lain pihak, Jaksa Penuntut Umum sebagai pihak yang memiliki kewenangan sebagai eksekutor akan merasa terbebani apabila harus melaksanakan penetapan hakim terhadap suatu permohonan restitusi yang tidak diketahuinya. Selain itu, hal tersebut juga dimaksudkan untuk menghindari keberatan dari pelaku tindak pidanayang merasa dirinya dihukum beberapa kali, mengingat ia telah dijatuhi hukuman, mungkin juga sudah menjalaninya selama beberapa waktu, tetapi kemudian ia dihadapkan padatuntutan hukum baru terkait kasus yang sudah diputuskan dirinya bersalah oleh hakim.

\section{Pengajuan Permohonan Restitusi bagi Korban Tindak Pidana Hanya Melalui LPSK: Tepatkah?}

Berdasarkan pemaparan sebelumnya, ketentuan Pasal 7 ayat (1) UU No. 13 Tahun 2006 memunculkan mekanisme baru dalam prosedur pengajuan hak atas restitusi yakni terlibatnya LPSK dalam prosedur pengajuan permohonan restitusi oleh korban tindak pidana. Dan sebagaimana telah dijelaskan

\footnotetext{
${ }^{20}$ Mekanisme tentang pengenaan pidana kurungan pengganti atau tidak diberikannya pengurangan masa pidana dan tidak mendapatkan pembebasan bersyarat bagi pelaku tindak pidana yang tidak mampu atau tidak mau membayar restitusi pada korban tindak pidana mungkin bukanlah mekanisme yang sesuai dengan harapan korban tindak pidana. Akan tetapi, mekanisme tersebut merupakan mekanisme yang terbaik yang dapat ditawarkan oleh negara bagi korban tindak pidana yang pembayaran restitusinya tidak dapat dipenuhi oleh pelaku tindak pidana.
} 
sebelumnya juga, keterlibatan LPSK ini ternyata justru dapat membuat korban harus menempuh jangka waktu yang lebih lama untuk mendapatkan hak atas restitusinya karena harus menjalani berbagai prosedur melalui LPSK terlebih dahulu baru kemudian melalui Jaksa Penuntut Umum apabila pengajuan permohonan restitusinya diajukan sebelum putusan pengadilan yang telah memperoleh kekuatan hukum tetap.

Selain masalah tersebut, ternyata masih ada satu hal terkait dengan LPSK yang menjadi menjadi hambatan bagi korban tindak pidana untuk memperoleh haknya atas restitusi, yaitu tidak jelasnya pengaturan tentang pihak atau lembaga yang berwenang untuk mengeksekusi pelaksanaan restitusi. Pasal 1 angka 3 UU No. 13 Tahun 2006 menyatakan bahwa Lembaga Perlindungan Saksi dan Korban, yang selanjutnya disingkat LPSK, adalah lembaga yang bertugas danberwenang untuk memberikan perlindungan dan hak-hak lain kepada Saksi dan/atau Korban sebagaimana diaturdalam undang-undang ini. Kemudian Pasal 12 menyatakan bahwa LPSK bertanggung jawab untuk menangani pemberian perlindungan dan bantuan pada Saksi dan Korban berdasarkantugas dan kewenangan sebagaimana diatur dalam undang-undang ini. Dalam UU No. 13 Tahun 2006 tidak ada satu pasal pun yang menyatakan bahwa salah satu kewenangan LPSK yakni melaksanakan putusan pengadilan atau penetapan hakim tentang restitusi yang diajukan oleh korban tindak pidana melalui LPSK. PP No. 44 Tahun 2008 yang menjabarkan ketentuan tentang restitusi bagi korban tindak pidana ternyata juga tidak mengatur secara tegas tentang kewenangan LPSK untuk melaksanakan putusan pengadilan atau penetapan hakim terkait restitusi.

Selanjutnya dalam UU No. 31 Tahun 2014, tidak ada perubahan perihal definisi LPSK. Akan tetapi, sehubungan dengan restitusi, undang-undang ini menambahkan ketentuan yang menyatakan bahwa dalam menyelenggarakan tugas sebagaimana dimaksud dalam Pasal 12, LPSK berwenangmelakukan penilaian ganti rugi dalam pemberian restitusi dan kompensasi (Pasal 12A ayat (1) huruf $\mathrm{j}$ ). Hal ini menunjukkan bahwa ada penambahan kewenangan bagi LPSK dalam hal restitusi bagi korban, tetapi hanya berupa kewenangan untuk melakukan penilaian ganti rugi dalam pemberian restitusi. LPSK masih belum diberikan kewenangan untuk melaksanakan putusan pengadilan atau penetapan hakim tentang permohonan restitusi yang diajukan oleh korban tindak pidana melalui lembaga tersebut.

Mengenai pihak yang diberi kewenangan untuk melaksanakan putusan pengadilan atau penetapan hakim, KUHAP dengan tegas mengaturnya dalam Pasal 6. Pasal 6 huruf a KUHAP menyatakan bahwa jaksa adalah pejabat yang diberi wewenang oleh undang-undangini untuk bertindak sebagai penuntut umum sertamelaksanakan putusan pengadilan yang telah memperolehkekuatan hukum tetap. Kemudian Pasal 6 huruf b KUHAP menyebutkan bahwa penuntut umum adalah jaksa yang diberi wewenang olehundang-undang ini untuk melakukan penuntutan danmelaksanakan penetapan hakim.Kewenangan jaksa sebagai eksekutor tersebut ditegaskan kembali dalam Pasal 1 angka $1-2^{21}$ dan

\footnotetext{
${ }^{21}$ Pasal 1
} 
Pasal 3022 Undang-Undang Nomor 16 Tahun 2004 tentang Kejaksaan Republik Indonesia (selanjutnya disingkat UU No. 16 Tahun 2004).

Berdasarkan pemaparan tersebut, jelaslah bahwa hanya lembaga kejaksaan yang diberikan wewenang oleh negara untuk melaksanakan penetapan hakim dan putusan pengadilan yang telah memperoleh kekuatan hukum tetap, tak terkecuali dalam mengeksekusi penetapan hakim dan putusan pengadilan terhadap permohonan restitusi yang diajukan oleh korban. Bila korban tindak pidana memilih untuk mendapatkan hak atas restitusinya melalui prosedur penggabungan perkara ganti kerugian dan pidana dalam KUHAP, maka pelaksana eksekusi atas putusan pidana tersebut jelas dilaksanakan oleh jaksa berdasarkan Pasal 270 KUHAP. ${ }^{23}$ Apabila korban tindak pidana memilih untuk mengikuti prosedur melalui LPSK sebagaimana diatur dalam UndangUndang Perlindungan Saksi dan Korban, memang tidak ada pasal yang menyatakan secara langsung bahwa jaksalah yang memiliki kewenangan untuk mengeksekusi penetapan hakim atau putusan pengadilan terhadap permohonan restitusi yang diajukan oleh korban tersebut. Akan tetapi, mengingat bahwa tidak ada satu ketentuan pun dalam Undang-Undang Perlindungan Saksi dan Korban yang menyatakan bahwa LPSK berwenang untuk melakukan eksekusi terhadap permohonan restitusi yang diajukan oleh korban tindak pidana, maka berdasarkan KUHAP dan UU No. 16 Tahun 2004, Jaksa Penuntut Umumlah yang berwenang melaksanakan penetapan hakim dan putusan pengadilan terhadap permohonan restitusi tersebut.

Selain itu, LPSK merupakan sebuah lembaga yang baru dibentuk pada tanggal 8 Agustus 2008 sebagai pelaksanaan salah satu amanat yang ada dalam UU No. 13 Tahun 2006 yang mengharuskan dibentuknya sebuah lembaga perlindungan saksi dan korban paling lambat setahun setelah undang-undang tersebut disahkan.Undang-undang tersebut secara tegas menyatakan bahwa LPSK adalah lembaga yangmandiri dalam artian merupakan sebuah lembaga yang independen tanpa campur tangan dari pihak manapun. Pertimbangan para perumus UU No. 13 Tahun 2006 dalam menetapkan model lembaga seperti ini terkait dengan beberapa pertimbangan danargumentasi yang telah dibangun dalam rapat pembahasan-pembahasanRUU ini sebagai berikut:

1. Keinginan untuk membuatlembaga yang secara khusus mengurusi masalah perlindungan saksi dankorban yang tidak berada di bawah

1. Jaksa adalah pejabat fungsional yang diberi wewenang oleh undang-undang untuk bertindak sebagai penuntut umum dan pelaksana putusan pengadilan yang telah memperoleh kekuatan hukum tetap serta wewenang lain berdasarkan undang-undang.

2. Penuntut Umum adalah jaksa yang diberi wewenang oleh Undang-Undang ini untuk melakukan penuntutan dan melaksanakan penetapan hakim.

${ }^{22}$ Pasal 30 ayat (1) huruf b:

Di bidang pidana, kejaksaan mempunyai tugas dan wewenang melaksanakan penetapan hakim dan putusan pengadilan yang telah memperoleh kekuatan hukum tetap.

23 Pasal 270 KUHAP:

Pelaksanaan putusan pengadilan yang telah memperoleh kekuatan hukumtetap dilakukan oleh jaksa, yang untuk itu panitera mengirimkan salinansurat putusan kepadanya. 
institusi yang sudah ada, yakni kepolisian atau kejaksaan, Komnas HAM atau Departemen Hukum danHAM karena diyakini pasti akan lebih baik dari segi kemampuan maupunkinerjanya. ${ }^{24}$

2. Institusi yang lain dinilai sudah memiliki beban tanggungjawab yang besar, oleh karena itu lebihbaik program perlindungan tidak lagi dibebani lagi kepada lembaga-lembaga tersebut. ${ }^{25}$

Sehubungan dengan hak atas restitusi bagi korban tindak pidana, kedua pertimbangan tersebut patutlah untuk dicerna kembali, terlebih mengingat bahwa LPSK tidak memiliki kewenangan untuk melaksanakan penetapan hakim dan putusan pengadilan sebagaimana Kejaksaan RI. Pertama, LPSK diyakini pasti akan lebih baik dari segi kemampuan maupun kinerjanya, apalagi dengan adanya ketidakpercayaan terhadap kinerja beberapa institusi termasuk Kejaksaan RI. Sebagaimana telah dijelaskan sebelumnya, LPSK merupakan suatu lembaga baru yang tentunya minim pengalaman, khususnya dalam membantu korban tindak pidana mendapatkan hak atas restitusinya. Hal ini jelas sangat berbeda dengan Kejaksaan RI yang sudah sangatberpengalaman dalam membantu korban tindak pidana untuk mendapatkan hak atas restitusinya melalui berbagai prosedur, misalnya gabungan gugatan ganti kerugian berdasarkan KUHAP atau mekanisme restitusi bagi korban tindak pidana perdagangan orang. ${ }^{26}$ Oleh sebab itu, justru Kejaksaan RI yang akan

24 Adanya ketidakpercayaan terhadap kinerja beberapa institusi tersebut yang menyebabkan mengapa pilihan mandiriini dikemukakan oleh para perumus UU No. 13 Tahun 2006. Hal ini juga terkait dengan trend yang ada, pada umumnya setelahreformasi, terjadi ketidakpercayaan terhadap institusi yang terkait pemerintah atau berada dalam pemerintah sehinggapara perumus awal RUU Perlindungan Saksi dan Korban mendorong agar program perlindungan saksi disupervisi oleh lembaga baru di luarlembaga yang telah ada. (Lihat Supriyadi Widodo Eddyono, UU Perlindungan Saksi Belum Progresif, ELSAM \&Koalisi Perlindungan Saksi, 2006).

25 Supriyadi Widodo Eddyono, et.al, "Pokok-Pokok Pikiran Penyusunan Cetak Biru Lembaga Perlindungan Saksi dan Korban: Usul Inisiatif Masyarakat”, (Jakarta: Indonesia Corruption Watch, 2008), hal. 6

26 Sebenarnya dapat dikatakan bahwa Kejaksaan RI pun telah berpengalaman dalam memperjuangkan semacam restitusi bagi negara yang dirugikan (baca: menjadi korban) dalam tindak pidana korupsi. Selaku penyidik tindak pidana korupsi, jaksa penyidik telah menginventarisasi kerugian negara yang ditimbulkan oleh tersangka pelaku tindak pidana korupsi. Dalam upaya memastikan nilai kerugian materiil tersebut, tak jarang kejaksaan melibatkan instansi pemeriksa keuangan atau auditor. Ketika berkas perkara dilimpahkan ke pengadilan, Jaksa Penuntut Umum memasukkan rincian kerugian negara tersebut dalam surat dakwaan. Kemudian Jaksa Penuntut Umum mengajukan alat bukti dan dalil-dalil dalam pembuktian untuk memperkuat dakwaannya, termasuk kerugian negara yang riil akibat perbuatan terdakwa. Dalam surat tuntutan, Jaksa Penuntut Umum mencantumkan klausul kewajiban membayar uang pengganti sebesar kerugian negara yang ditimbulkan dengan catatan apabila terdakwa tidak sanggup untuk membayarnya, maka akan dikenakan hukuman penjara untuk menggantikan kewajiban uang pengganti yang tidak bisa ditunaikannya tersebut. Untuk memastikan terdakwa tidak lari dari kewajibannya atau berpura-pura tidak mampu untuk membayar uang pengganti setelah diputus bersalah oleh hakim, maka kejaksaan akan 
lebih baik dari segi kemampuan maupun kinerjanya dalam membantu korban tindak pidana untuk mendapatkan hak atas restitusinya apabila dibandingkan dengan LPSK.

Kedua, mengenai masalah beban tanggungjawab yang besar. Dengan kedudukan LPSK yang hanya berada di ibukota negara tentu akan menjadi beban yang teramat berat bagi LPSK untuk menjangkau korban tindak pidana di seluruh Indonesia. Beban tersebut bukan saja mengenai personil yang terbatas, tetapi juga menyangkut anggaran dan infrastruktur yang tidak memadai. Sementara apabila hal tersebut dijadikan sebagai salah satu kewenangan kejaksaan, maka dapat dimanfaatkan dan dimaksimalkan dengan kedudukan kejaksaan yang tersebar diseluruh Indonesia. Terlebih bila dihubungkan dengan kewenangan kejaksaan dibidang penuntutan, tentu akan semakin mempermudah akses dan koordinasi dengan aparat penegak hukum lain yang ada dalam sistem peradilan pidana yang berkepentingan dalam memperjuangkan hak korban tindak pidana.

Berdasarkan pemaparan tersebut, maka tidaklah tepat bila permohonan restitusi hanya bisa diajukan oleh korban tindak pidana melalui LPSK. Berbeda dengan pertimbangan dari para perumus UU No. 13 Tahun 2006 bahwa LPSK diyakini akan memiliki kemampuan dan kinerja yang lebih baik dari lembaga lain, termasuk Kejaksaan RI, Penulis justru menemukan bahwa LPSK memiliki sejumlah kekurangan bila dibandingkan dengan Kejaksaan RI sehingga akan lebih tepat bila kewenangan untuk mengajukan restitusi bagi korban tindak pidana berada pada Kejaksaan RI.

\section{Penutup}

\section{Kesimpulan}

Pada dasarnya mekanisme pemberian ganti rugibagi korban tindak pidana sudah diatur dalam KUHAP. Selain itu, Undang-Undang Perlindungan Saksi dan Korbanjuga telah memberikan jalan bagi korbantindak pidana untuk mendapatkan ganti kerugian yang berupa restitusi dari pelaku tindak pidana. Akan tetapi, kedua ketentuan tersebut memiliki sejumlah masalah dalam implementasinya, antara lain:

1) Terbatasnya jenis dan jumlah kerugian yang dapat dimintakan oleh korban tindak pidana apabila menggunakan mekanisme penggabungan gugatan ganti kerugian yang diatur dalam KUHAP. Belum lagi prosedur pengajuannya yang tidak sederhana dan

melakukan pelacakan aset-aset yang dimiliki olehnya, baik yang masih atas namanya atau telah dialihkan ke pihak lain yang dilakukan sebagai upaya untuk mengaburkan kepemilikannya atau untuk menghindari tindakan hukum dari aparat penegak hukum. Setelah itu kejaksaan akan mengeksekusi asetnya dan selanjutnya dilelang untuk mengganti kerugian negara yang harus dipikul oleh pelaku tindak pidana korupsi tersebut. 
membutuhkan peran aktif dari korban tindak pidana sendiri dalam prosesnya.

2) Apabila pengajuan restitusi menggunakan proses yang diatur dalam UU No. 31 Tahun 2014, maka tidak semua korban tindak pidana dapat mengajukan restitusi sebagai haknya, karena tidak semua tindak pidana dapat diajukan restitusi. Penetapan suatu tindak pidana yang dapat diajukan restitusi oleh korbannya ditentukan oleh LPSK. Hallain yang menimbulkan permasalahan yakni mekanisme dan prosedur pengajuan restitusi serta pelaksanaan restitusinya mengingat LPSK tidak termasuk dalam sistem peradilan pidana, dan bukan merupakan aparat penegak hukum yang memiliki kewenangan eksekutoral.

\section{Saran}

Untuk itu diperlukan mekanisme baru bagi korban tindak pidana untuk memperjuangkan haknya untuk mendapatkan restitusi.Mekanisme baru tersebut haruslah diatur dalam KUHAP sebagai ketentuan formil yang menjadi rujukan bagi sistem peradilan pidana dalam melaksanakan tugasnya. Hal ini sekaligus untuk mengisi kekosongan dan ketidakjelasan dalam hukum acara selama ini, sekaligus memberikan kepercayaan kepada Kejaksaan RI sebagai instansi yang telah berpengalaman dan memiliki kewenangan yang secara inheren telah termanifestasi dalam pelaksana tugas pokok dan fungsinya sebagai aparat penegak hukum. 


\section{Daftar Pustaka}

\section{Buku}

Atmasasmita, Romli. Penulisan Karya Ilmiah tentang Masalah Santunan Terhadap Korban Tindak Pidana, Jakarta: Badan Pembinaan Hukum Nasional, Departemen Kehakiman, 1992.

Eddyono, Supriyadi Widodo. Lembaga Perlindungan Saksi dan Korban di Indonesia: Sebuah Pemetaan Awal, Jakarta: Indonesia Corruption Watch, 2007.

Lembaga Perlindungan Saksi dan Korban: Usul Inisiatif Masyarakat, Jakarta: Indonesia Corruption Watch, 2008.

-------- et.al. Masukan Terhadap Perubahan UU No. 13 Tahun

2006 tentang Perlindungan Saksi dan Korban. Jakarta: Koalisi Perlindungan Saksi dan Korban, 2014.

Hamzah, Andi. Perlindungan Hak-hak Asasi Manusia dalam Kitab UndangUndang Hukum Acara Pidana, Bandung: Binacipta, 1986.

Harahap, M. Yahya. Pembahasan Permasalahan dan Penerapan KUHAP Jilid II, Jakarta: Sarana Bakti Semesta, 1985.

Muladi. Hak Asasi Manusia, Politik dan Sistem Peradilan Pidana, Semarang: Badan Penerbit Universitas Diponegoro, 2002.

Wagiman, Wahyu dan Zainal Abidin. Praktik Kompensasi dan Restitusi di Indonesia: Sebuah Kajian Awal, Jakarta: Indonesia Corruption Watch, 2007.

Pemerintah tentang Pemberian Kompensasi dan Restitusi, serta Bantuan bagi Saksi dan Korban: Usul Inisiatif Masyarakat, Jakarta: Indonesia Corruption Watch, 2007.

\section{Peraturan}

Undang-Undang Hukum Acara Pidana. UU No. 8 Tahun 1981. LN No. 76 Tahun 1981. TLN No. 3258.

Undang-Undang Kejaksaan Republik Indonesia, UU No. 16 Tahun 2004, LN No. 67 Tahun 2004.

Undang-Undang Perlindungan Saksi dan Korban. LN No. 64 Tahun 2006. TLN No. 4635.

Undang-Undang Pemberantasan Tindak Pidana Perdagangan Orang. UU No. 21 Tahun 2007. LN No. 58 Tahun 2007. TLN No. 4720. 
Peraturan Pemerintah Pemberian Kompensasi, Restitusi, dan Bantuan kepada Saksi dan Korban. PP No. 44 Tahun 2008. LN No. 84 Tahun 2008. TLN No. 4860.

Undang-Undang Perubahan Atas Undang-Undang Nomor 13 Tahun 2006 Tentang Perlindungan Saksi dan Korban. UU No. 31 Tahun 2014. LN No. 293 Tahun 2014. TLN No. 5602.

Naskah Akademik RUU LPSK (Rancangan Undang-Undang Lembaga Perlindungan Saksi dan Korban) Tahun 2014.

Rancangan Undang-Undang Hukum Acara Pidana Tahun 2012. 